\title{
Character Association and Path Analysis Studies at Genotypic Level on Some Genotypes of Safflower (Carthamus tinctorius L.)
}

\author{
Monika Paikara* and Roshan Parihar \\ Department of Genetics and Plant Breeding, Barrister Thakur Chhedilal College of \\ Agriculture and Research Station, Sarkanda (IGKV Raipur), Bilaspur, \\ Chhattisgarh, India-495004 \\ *Corresponding author
}

\begin{abstract}
A B S T R A C T
Safflower is one of the old domesticated crops and mostly cultivated for oil purpose. Large numbers of variability were found in this crop and through the successful breeding programme the problems can be eradicated. The experiment was conducted at BTC College of Agriculture and Research station, Bilaspur (C.G.) in Rabi season during 201718.The experimental material consisted of a population of 26 genotypes included two checks A1 (NC) and PBNS-12 (C) with laid out in Randomized block design. Genotypic correlation studies show that seed yield had exhibit highest significant positive correlation with harvest index (0.806) followed by Biological yield (0.801), 100 seed weight $(0.677)$, volume weight $(0.563)$, branches /plant $(0.474)$. Whereas non -significant but positive with rosette period $(0.360)$, plant height $(0.351)$, days to maturity $(0.324)$, days to flowering (0.306), capitulum per plant (0.285), seeds per capitulum (0.254). At the genotypic level path analysis results shows that seed yield had maximum direct positive effect with biological yield (0.682) followed by harvest index (0.524), rosette period (0.087), capitulum per plant (0.056), plant height $(0.012)$. Whereas 100 seed weight $(-0.100)$, days to $50 \%$ flowering $(-0.050)$, branches per plant $(-0.042)$, days to maturity $(-0.035)$ seeds per capitulum (-0.037) volume weight $(-0.016)$ had negative direct effect on seed yield.
\end{abstract}

\section{Introduction}

Safflower (Carthamus tinctorius L.) is one of the oldest domesticated crops. It has been grown since ancient times both as a dye as well as an oilseed crop in a wide range of geographical regions (Knowles, 1976). It is a member of the family Compositae or Asteraceae, genus- Carthamus, tribeTubiflorae, sub division-Angiosperm of division- Phanerogams.
It is mainly grown in Maharashtra, Karnataka and parts of Andhra Pradesh, Madhya Pradesh, Orissa, Bihar, etc. Maharashtra and Karnataka are the two most important safflower growing states accounting for 72 and 23 per cent of area and 63 and 35 per cent of production, respectively. Safflower is cultivated in an area of 600 hectares with a production of 200 tonnes and a productivity of $333 \mathrm{~kg} /$ hectare in Chhattisgarh. Whereas in India the Safflower is grown in an area of 1 , 
78,000 hectares with production of $1,14,000$ tonnes and productivity of $641 \mathrm{~kg} /$ hectare in the year 2013-14 (Anonymous, 2015).

It is multi used oilseed crop i.e. cooking oil, bird seed, petals used as natural dyes and medicinal use etc. It is mainly grown for oil purpose in India. Safflower, a multipurpose crop, has been grown for centuries in India and for its quality oil rich in polyunsaturated fatty acids (linoleic acid, 78\%). Safflower flowers are known to have many medicinal properties for curing several chronic diseases.

Correlation coefficient analyses help researchers to distinguish significant relationship between traits. Stepwise regression can reduce effect of non-important traits in regression model, in this way traits accounted for considerable variations of dependent variable are determined (Agrama, 1996). Path analysis has been extensively used for segregating correlation between yield and its components in field crops. Path analysis is used to determine the amount of direct and indirect effects of the variables on the dependent variable. It confirms the magnitude of correlation by partioning the effects into direct and indirect effects. The core objective of current research was to find out the dependence association of grain yield with yield related characters in safflower genotypes and to recognize the most important indirect selection criteria for genetic improvement of these characters through path analysis.

\section{Materials and Methods}

The present research work was carried out at the Research cum Instructional farm of BTC College of Agriculture and Research station, Bilaspur (C.G.), Rabi, 2017-18. The experimental material consisted of a population of 26 genotypes included two checks A-1 (Annigeri-1) Spiny (National Check) and PBNS-12 (Check) and 24 genotypes viz. GMU-7368, GMU-3635, AKS94 -2 x GMU- 3821, NARI-118, SSF-995 X GMU-3806, GMS-NARI-57 (Cross-13), AKS-91-1-1 x GMU- 3802, AKS-91-1-1 x GMU- 3809, MS-06 X PBNS-72(CROSS-15), RVS-12-13 X PBNS-12, Manjeera X GMU7403, AKS-91-1-1 X GMU-3806, PBNS-12 X GMU-4055, RSS-11-17 X GMU-4037, GMU6106 X Manjeera, GMU-7403 X JSF-1, RVS12-13 X Manjeera, GMU 7403 X Manjeera

The crop was raised in the month of November 2017 in Randomized Block Design (RBD) with three replications with the plot size for each entries was of 4 rows of 4 meter length spaced $50 \mathrm{~cm}$ apart make a plot size of $8 \mathrm{~m}^{2}$.The dose of fertilizer application will be 60:40:30 kg/ha. Nitrogen was applied in two split doses whereas $\mathrm{P}$ and $\mathrm{K}$ were applied as basal dose. Observations were recorded on five randomly selected competitive plants from each plot in each replication. The characters selected for the observations are Rosette period (Days), Days to 50\% flowering, Days of maturity, Plant height (cm), No. of capitulum per plant, No. of seeds per capitulum, No. of branches per plant, 100 seed weight (gms.), Volume weight (gms./100 $\mathrm{ml})$, Biological yield per plot $(\mathrm{kg})$, Harvest index (\%), Seed yield / plot $(\mathrm{kg})$.

\section{Statistical Analysis: Correlation coefficient analysis (Character association)}

Correlation coefficient (r) was calculated for all possible combination of yield and its component parameters by using the standard procedure given by Searle et al., (1961).

Correlation coefficient between two characters $\mathrm{X}$ and $\mathrm{Y}$ were calculated using the following formula:

$r(X Y)=\operatorname{Cov} \cdot(X Y) / \sqrt{V(X) \cdot V(Y)}$

where, 
$r(X Y)=$ correlation coefficient between $\mathrm{x}$ and y characters

Cov. $(\mathrm{XY})=$ covariance between $\mathrm{X}$ and $\mathrm{Y}$

$\mathrm{V}(\mathrm{X})=$ variance of $\mathrm{X}$

$\mathrm{V}(\mathrm{Y})=$ variance of $\mathrm{Y}$

Correlation estimates at genotypic level were computed by using the formula given by (Snedecor and Cochran, 1989)

$\operatorname{rg}=\operatorname{COVgxy} /\left(\sigma^{2} \operatorname{gx} x \sigma^{2} \text { gy }\right)^{1 / 2}$

\section{Path coefficient analysis}

The path analysis was originally developed by Wright (1921) and elaborated by Dewey and $\mathrm{Lu}$ (1959). Path coefficient analysis splits the genotypic correlation coefficient into measures of direct and indirect effects. It measures the direct and indirect contribution of independent variables on dependent variable.

After calculation the value of path coefficient i.e. the residual effect was estimated by the method suggested by Singh and Chaudhary (1985)

Residual effect $(\mathrm{R})=\sqrt{1 \text {-di.rXi.X }} \mathrm{j}$

Where,

di=direct effect of $i^{\text {th }}$ character

rXi. $X j=$ correlation coefficient of $i^{\text {th }}$ character with $\mathrm{j}^{\text {th }}$ character

The results of path coefficient analysis were interpreted as per following scale suggested by Lenka and Mishra (1973).

\section{Results and Discussion}

Correlation analysis of genotypic level for yield and other yield characters are presented in Table 1. Seed yield per plot $(\mathrm{kg})$ is taken as dependent variable whereas other traits were selected as independent variable for the correlation analysis. The results are discussed character wise.

\section{Seed yield}

Table 1 resulted that seed yield per plot $(\mathrm{kg})$ had highest significant positive correlation with harvest index \% (0.806) followed by biological yield per plot $(\mathrm{kg})(0.801), 100$ seed weight (gms) (0.677), volume weight (gms/100 $\mathrm{ml}$ water volume) (0.563) and number of branches per plant (0.474). Whereas non significant but positive correlation with rosette period (0.360), plant height $(\mathrm{cm}) \quad(0.351)$,days to maturity $(0.324)$,days to $50 \%$ flowering (0.306), number of capitulum per plant (0.285) and number of seeds per capitulum (0.254).

\section{Rosette period}

It had significant positive correlation with days to $50 \%$ flowering (0.777) followed by days to maturity (0.734). Similar results were found by Perveen (2016), Pavithra et al., (2016) and Manjhi (2017). Rosette period had positive non-significant correlation with harvest index \% (0.363), seed yield per plot (kg) (0.360), 100 seed weight (gms) (0.344), volume weight (gms./100 $\mathrm{ml}$ water volume) (0.324), biological yield per plot $(\mathrm{kg})(0.255)$, plant height $(\mathrm{cm})(0.205)$, number of seeds per capitulum (0.108) and number of capitulum per plant (0.102). Similar results were found by Perveen (2016) and Pavithra et al., (2016).

Rosette period had negative non significant correlation with number of branches per plant $(-0.070)$.

\section{Days to 50\% flowering}

It had significant positive correlation with days to maturity (0.897) followed by plant height $(\mathrm{cm})(0.460)$. This result is supported by the results of Golker et al., (2011), Paikara 
(2013), Ahmadzadeh (2013), Kairimi et al., (2014), Bagri (2014), Pattar (2014), Puspavalli et al (2015), Nag (2015), Achhale (2016), Kumar (2016), Perveen (2016) and Manjhi (2017). Days to $50 \%$ flowering had positive non-significant correlation with number of capitulum per plant (0.379) followed by seed yield per plot (kg) (0.306), biological yield per plot (kg) (0.285), 100 seed weight (gms.) (0.244), harvest index \% (0.228), volume weight (gms/100 ml water volume) (0.186), number of branches per plant $(0.183)$ and number of seeds per capitulum (0.126). Similar results were found by Golker et al., (2011), Paikara (2013), Gopal et al., (2014), Nag (2015), Puspavalli et al., (2015), Achhale (2016), Kumar (2016), Perveen (2016) and Manjhi (2017).

\section{Days to maturity}

It had significant positive correlation with plant height $(\mathrm{cm})(0.503)$ followed by number of capitulum per plant (0.418). This result is supported by results of Golker et al., (2011), Ahmadzadeh (2013), Achhale (2016) and Manjhi (2017).

Days to maturity had positive non- significant correlation with seed yield per plot $(\mathrm{kg})$ (0.324), 100 seed weight (gms.) (0.307), biological yield per plot $(\mathrm{kg})(0.298)$, number of seeds per capitulum (0.275), harvest index $\%$ (0.255), volume weight (gms /100 ml water volume) (0.174) and number of branches per plant (0.093).Similar results were found by Golker et al.,(2011), Pavithra (2013), Bagri (2014), Gopal et al., (2014), Puspavalli et al., (2015), Achhale (2016), Perveen (2016) and Kumar (2016).

\section{Plant height (cm)}

It had significant positive correlation with number of capitulum per plant (0.976) followed by number of branches per plant
(0.714), number of seeds per capitulum (0.669), 100 seed weight (gms.) (0.466) and biological yield per plot (kg) (0.413). Similar results were found by Roopa and Ravikumar (2008), Shivani et al., (2010), Pavithra (2013)Karimi et al., (2014), Nezhad and Talebi (2015), Sirel and Aytac (2016) and Manjhi (2017).

Plant height $(\mathrm{cm})$ had positive non significant correlation with seed yield per plot $(\mathrm{kg})$ (0.351) followed by harvest index \% (0.182) and volume weight (gms./100 ml water volume) (0.146). Similar results were found by Karimi et al., (2014) and Nag (2015).

\section{Number of capitulum per plant}

It had significant positive correlation with number of branches per plant (0.732) followed by number of seeds per capitulum (0.693). Similar results were found by Roopa and Ravikumar, (2008), Perveen (2016) and Manjhi (2017).

Number of capitulum per plant had found positive non-significant correlation with 100 seed weight (gms.) (0.375), biological yield per plot $(\mathrm{kg})(0.323)$, seed yield per plot $(\mathrm{kg})$ (0.285) harvest index \% (0.174) and volume weight (gms./100 ml water volume) (0.059). Similar results were found by Roopa and Ravikumar, (2008), Pattar (2014), Bagri (2014), Gopal et al., (2014), Puspavalli et al., (2015), Perveen (2016), Puspavalli et al., (2017), Manjhi (2017) and Mohamed and Elmogtaba (2018).

\section{Number of seeds per capitulum}

It had positive non-significant correlation with biological yield per plot $(\mathrm{kg})(0.354)$, seed yield per plot $(\mathrm{kg})(0.254), 100$ seed weight (gms) (0.347), number of branches per plant (0.321), volume weight (gms $/ 100 \mathrm{ml}$ water volume) (0.319) and harvest index \% (0.061). 
Similar results were found by Roopa and Ravikumar, (2008), Gopal et al., (2014),Pattar (2014), Kumar (2016) and Manjhi (2017).

\section{Number of branches per plant}

It had significant positive correlation with biological yield per plot $(\mathrm{kg})(0.478)$, seed yield per plot $(\mathrm{kg})(0.474)$ and 100 seed weight (gms) (0.434) and similar results were found by Perveen (2016) and Achhale (2016).

Number of branches per plant had positive non- significant correlation with harvest index $\%$ (0.346) and volume weight (gms /100 ml water volume) (0.147). This result is also supported with the findings of Roopa and Ravikumar (2008) and Gopal et al., (2014).

\section{0 seed weight (gms)}

It had significant positive correlation with biological yield per plot $(\mathrm{kg})(0.783)$, seed yield per plot (kg) (0.677) and volume weight (gms./100 ml water volume) (0.399). Our results are supported with the findings of Hoshang et al.,(2013), Hussain et al., (2014), Tamoor et al., (2014), Nag (2015), Kumar (2016),Achhale (2016), Semahegn and Tesfaye (2016), Manjhi (2017), Valli (2016) and Puspavalli et al.,(2017)

100 seed weight (gms.) had positive nonsignificant correlation with harvest index \% (0.362).

\section{Volume weight (gms /100 ml water volume)}

It had significant positive correlation with biological yield per plot $(\mathrm{kg})(0.641)$ and seed yield per plot $(\mathrm{kg})(0.563)$. Similar result was found by Manjhi (2017).

Volume weight (gms /100 ml water volume) had non-significant positive correlation with harvest index \% (0.253). Similar result was found by Pavithra (2013).

\section{Biological yield per plot (kg)}

It had positive significant correlation with seed yield per plot $(\mathrm{kg})(0.887)$ and harvest index \% (0.438). Similar results were found by Kumar (2010), Maryam et al., (2011), Salmati et al.,(2011), Ahmadzadeh (2013), Hoshang et al.,(2013), Kumar (2016) and Achhale (2016).

\section{Harvest index\%}

It had significant positive correlation with seed yield per plot $(\mathrm{kg})(0.801)$. This result is supported with the results of Shivani et al., (2010), Maryam et al., (2011), Nezhad and Talebi (2015), Kumar (2016) and Manjhi (2017), Jadhav et al., (2018).

\section{Path analysis (Genotypic) results}

Path analysis of genotypic level when seed yield taken as dependent trait at genotypic level.

Table 2 resulted that seed yield per plot $(\mathrm{kg})$ had maximum direct positive effect with biological yield per plot (kg) (0.682) followed by harvest index $\%(0.524)$, rosette period (0.087), number of capitulum per plant (0.056) and plant height $(\mathrm{cm})(0.012)$. Whereas 100 seed weight (gms.) (-0.100), days to $50 \%$ flowering (-0.050), number of branches per plant (-0.042), days to maturity (-0.035), number of seeds per capitulum (-0.037) and volume weight (gms /100 ml water volume) (0.016) had negative direct effect on seed yield per plot $(\mathrm{kg})$ (Table 2). The characters under path analysis are discussed character wise.

\section{Rosette period}

It had positive direct positive effect $(0.087)$ on seed yield per plot (kg) (0.360) but it had indirect positive effect through days to $50 \%$ flowering (0.069), days to maturity (0.068), 
plant height $(\mathrm{cm})(0.027)$, number of capitulum per plant (0.017), number of seeds per capitulum (0.022), 100 seed weight (gms.) (0.046), volume weight (gms $/ 100 \mathrm{ml}$ water volume) (0.036), biological yield per plot $(\mathrm{kg})$ (0.038) and harvest index \% (0.032) (Table 2).

\section{Days to $50 \%$ flowering}

It had direct negative effect $(-0.050)$ on seed yield per plot $(\mathrm{kg})(0.306)$ but it had indirect negative effect through days to maturity ($0.045)$ followed by plant height $(\mathrm{cm})(-0.025)$, number of capitulum per plant $(-0.021)$ and number of branches per plant.

\section{Days to maturity}

It had direct negative effect $(-0.035)$ on seed yield per plot $(\mathrm{kg})(0.324)$ but it had indirect negative effect through plant height $(\mathrm{cm})$ (0.017 ), number of capitulum per plant ($0.014), 100$ seed weight (gms) (-0.011) and biological yield per plot (kg) (-0.010).

\section{Plant height $(\mathrm{cm})$}

It had direct positive effect (0.012) on seed yield per plot $(\mathrm{kg})(0.351)$ but it had indirect positive effect through number of capitulum per plant (0.012).

\section{Number of capitulum per plant}

It had direct positive effect (0.056) on seed yield per plot $(\mathrm{kg})(0.285)$ but it had indirect positive effect through number of seeds per capitulum (0.037) followed by number of branches per plant (0.039), 100 seed weight (gms.) (0.015), biological yield per plot $(\mathrm{kg})$ (0.012) and harvest index \% (0.012).

\section{Number of seeds per capitulum}

It had direct negative effect $(-0.037)$ on seed yield per plot $(\mathrm{kg})(0.254)$ but it had indirect negative effect through plant height $(\mathrm{cm})$ (-
$0.024)$ and number of capitulum per plant ($0.024)$.

\section{Number of branches per plant}

It had direct negative effect $(-0.042)$ on seed yield per plot $(\mathrm{kg})(0.474)$ but it had indirect negative effect through plant height $(\mathrm{cm})$ ($0.029)$, number of capitulum per plant ($0.029)$, harvest index $\%(0.017)$ and biological yield per plot $(\mathrm{kg})(-0.015)$.

\section{0 seed weight (gms.)}

It had direct negative effect $(-0.100)$ on seed yield per plot $(\mathrm{kg})(-0.100)$ but it had indirect negative effect through biological yield per plot $(\mathrm{kg})(-0.071)$ followed by harvest index \% $(-0.046)$, rosette period $(-0.053)$ and days to $50 \%$ flowering $(-0.032)$.

\section{Volume weight (gms /100 ml water volume)}

It had direct negative effect $(-0.016)$ on seed yield per plot $(\mathrm{kg})(-0563)$ but it had indirect negative effect through biological yield per plot (kg) (0.010).

\section{Biological yield per plot (kg)}

It had direct positive effect(0.682) on seed yield per plot $(\mathrm{kg})(0.887)$ but it had indirect positive effect through volume weight (gms $/ 100 \mathrm{ml}$ water volume) $(0.410)$, harvest index $\%$ (0.386), rosette period (0.303) and days to $50 \%$ flowering $(0.203)$.

\section{Harvest index \%}

It had direct positive effect (0.524) on seed yield per plot $(\mathrm{kg})(0.801)$ but it had indirect positive effect through biological yield per plot (kg) (0.297), 100 seed weight (gms.) (0.243), number of branches per plant (0.214) and rosette period $(0.194)$. 
Table.1 Genotypic correlation coefficient of yield and its contributing traits

\begin{tabular}{|c|c|c|c|c|c|c|c|c|c|c|c|c|c|}
\hline S.No. & Character & $\begin{array}{c}\text { Rosette } \\
\text { Period }\end{array}$ & $\begin{array}{l}\text { Days to50\% } \\
\text { Flowering }\end{array}$ & $\begin{array}{r}\text { Days to } \\
\text { Maturity }\end{array}$ & $\begin{array}{l}\text { Plant } \\
\text { Height }\end{array}$ & $\begin{array}{l}\text { Capitulum } \\
\text { /Plant }\end{array}$ & $\begin{array}{c}\text { Seeds/ } \\
\text { Capitulum }\end{array}$ & $\begin{array}{c}\text { Branches/ } \\
\text { Plant }\end{array}$ & $\begin{array}{c}100 \text { Seed } \\
\text { Weight }\end{array}$ & $\begin{array}{c}\text { Volume } \\
\text { weight }\end{array}$ & $\begin{array}{l}\text { Biological } \\
\text { Yield }\end{array}$ & $\begin{array}{c}\text { Harvest } \\
\text { /Index }\end{array}$ & Seed Yield \\
\hline 1 & RP & 1.000 & $0.777 * *$ & $0.734 * *$ & 0.2057 & 0.102 & 0.108 & -0.070 & 0.344 & 0.324 & 0.255 & 0.363 & 0.360 \\
\hline 2 & DF & & 1.000 & $0.897 * *$ & $0.460^{*}$ & 0.379 & 0.126 & 0.183 & 0.242 & 0.186 & 0.285 & 0.228 & 0.306 \\
\hline 3 & DM & & & 1.000 & $0.503^{* *}$ & $0.418^{*}$ & 0.275 & 0.093 & 0.307 & 0.174 & 0.298 & 0.255 & 0.324 \\
\hline 4 & PH & & & & 1.000 & $0.972 * *$ & $0.669 * *$ & $0.714^{* *}$ & $0.466^{*}$ & 0.146 & $0.413^{*}$ & 0.182 & 0.351 \\
\hline 5 & $\mathbf{C P}$ & & & & & 1.000 & 0.693 ** & $0.732 * *$ & 0.375 & 0.059 & 0.323 & 0.174 & 0.285 \\
\hline 6 & SC & & & & & & 1.000 & 0.321 & 0.347 & 0.319 & 0.354 & 0.061 & 0.254 \\
\hline 7 & BP & & & & & & & 1.000 & $0.434 *$ & 0.147 & $0.478^{*}$ & 0.346 & $0.474 *$ \\
\hline 8 & SW & & & & & & & & 1.000 & $0.399 *$ & $0.783^{* * *}$ & 0.362 & $0.677 * *$ \\
\hline 9 & VW & & & & & & & & & 1.000 & $0.641^{* * *}$ & 0.253 & $0.563^{* *}$ \\
\hline 10 & BY & & & & & & & & & & 1.000 & $0.438 *$ & $0.887 * *$ \\
\hline 13 & HI & & & & & & & & & & & 1.000 & $0.801 * *$ \\
\hline \multicolumn{14}{|c|}{$\begin{array}{l}\text { Abbreviations used : (Rosette Period-RP), (Days to 50\% Flowering- DF), ( Days to Maturity-DM), ( Plant Height -PH), (Capitulum/ Plant -CP), (Seeds /Capitulum -SC), (Branches/Plant -BP) (10) } \\
\text { Seed Weight -SW), (Volume Weight -VW), (Biological Yield -BY), ( Harvest Index -HI) }\end{array}$} \\
\hline
\end{tabular}

Table.2 Path correlation matrix of yield and its contributing traits at genotypic level

\begin{tabular}{|c|c|c|c|c|c|c|c|c|c|c|c|c|c|}
\hline \multirow[t]{2}{*}{ Character } & \multirow{2}{*}{$\begin{array}{c}\text { Corr. } \\
\text { With yield }\end{array}$} & \multirow{2}{*}{$\begin{array}{l}\text { Direct } \\
\text { Effect }\end{array}$} & \multicolumn{11}{|c|}{ Indirect effect } \\
\hline & & & $\mathbf{R P}$ & D F & DM & PH & $\mathbf{C P}$ & SC & BP & SW & V W & BY & HI \\
\hline Rosette Period & 0.360 & 0.087 & -- & 0.069 & 0.068 & 0.027 & 0.017 & 0.022 & 0.001 & 0.046 & 0.036 & 0.038 & 0.032 \\
\hline $\begin{array}{l}\text { Days to 50\% } \\
\text { Flowering }\end{array}$ & 0.306 & $\overline{-}-$ & -0.039 & -- & $\begin{array}{c}- \\
0.045\end{array}$ & -0.025 & $\begin{array}{c}- \\
0.021\end{array}$ & $\begin{array}{c}- \\
0.009\end{array}$ & -0.012 & -0.016 & -0.011 & -0.019 & -0.011 \\
\hline Days to Maturity & 0.324 & $\stackrel{-}{0.035}$ & -0.027 & - & -- & -0.017 & $\begin{array}{c}- \\
0.014\end{array}$ & - & -0.002 & -0.011 & -0.005 & -0.010 & -0.009 \\
\hline Plant Height & 0.351 & 0.012 & 0.004 & 0.006 & 0.006 & -- & 0.012 & 0.008 & 0.009 & 0.005 & 0.001 & 0.004 & 0.003 \\
\hline Capitulum/ Plant & 0.285 & 0.056 & 0.011 & 0.024 & 0.023 & 0.055 & -- & 0.037 & 0.039 & 0.015 & -0.002 & 0.012 & 0.012 \\
\hline Seeds /Capitulum & 0.254 & $\stackrel{-}{0.037}$ & -0.009 & $\begin{array}{c}- \\
0.007\end{array}$ & $\begin{array}{c}- \\
0.010\end{array}$ & -0.024 & $-\overline{-}$ & -- & -0.006 & -0.006 & -0.008 & -0.005 & -0.004 \\
\hline Branches/ Plant & $0.474 *$ & $\overline{-}$ & -0.001 & $\overline{-}$ & $\overline{-}$ & -0.029 & $\begin{array}{c}- \\
0.029\end{array}$ & $\begin{array}{c}- \\
0.007\end{array}$ & -- & -0.013 & -0.002 & -0.015 & -0.017 \\
\hline 100 Seed Weight & $0.677 * *$ & $\overline{-}$ & -0.053 & 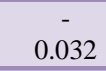 & $\overline{-}$ & -0.039 & $\overline{-}-$ & $\overline{-}$ & -0.031 & -- & -0.031 & -0.071 & -0.046 \\
\hline Volume Weight & $0.563 * *$ & $\stackrel{-}{0.016}$ & -0.007 & $\overline{-}-$ & $\overline{-}$ & -0.001 & 0.000 & $\overline{-}$ & -0.001 & -0.005 & -- & -0.010 & -0.005 \\
\hline Biological Yield & $0.887 * *$ & 0.682 & 0.303 & 0.262 & 0.203 & 0.215 & 0.140 & 0.095 & 0.244 & 0.486 & 0.410 & -- & 0.386 \\
\hline Harvest Index & $0.801 * *$ & 0.524 & 0.194 & 0.116 & 0.138 & 0.123 & 0.110 & 0.062 & 0.214 & 0.243 & 0.153 & 0.297 & -- \\
\hline
\end{tabular}


It could be concluded from the present investigation that the characters like harvest index $\%$, biological yield per plot $(\mathrm{kg})$, rosette period, number of capitulum per plant and plant height $(\mathrm{cm})$ possessed strong positive association and high magnitude of positive direct effects on seed yield per plot $(\mathrm{kg})$ and the indirect effects of most of the characters via., these characters were positive and some characters were found negative during the investigation.

The results of the present investigations are also confirmed by the findings of Roopa and Ravikumar (2008), Pavithra (2013), Nag (2015), Perveen (2016), Achhale (2016) and Jadhav et al., (2017).

\section{References}

Achhale, D., (2016). Screening of safflower (Carthamus tinctorius L.) genotypes for drought tolerance. M.Sc.(Ag.) Thesis, Rajmata Vijayaraje Scindia Krishi Vishwavidyalaya, Madhya pradesh.

Agrama, H.A.S. 1996. Sequential path analysis of grain yield and its components in maize. Plant Breeding, 115: 343-346.

Ahmadzadeh, A. 2013. Genetic diversity and classification of spring safflower (Carthamus tinctorius L.) cultivars using morphological characters. Advances in Bioresearch, 4(4): 125 131.

Anonymous. (2015). Annual group meeting on safflower. Directors report, 19-21.

Bagri, A.K. 2014. Screening of safflower ((Carthamus tinctorius L.) genotypes of drought tolerance. M.Sc.(Ag.) Thesis, Rajmata Vijayaraje Scindia Krishi Vishwavidyalaya, Gwalior.

Dewey, D.R. and Lu, K.H. 1959.A correlation and path coefficient analysis of components in crested wheat grass seed production.Agron. J., 51:515518.

Golkar, P., Arzani,A. and Rezaei, A.M., (2011). Determining relationships among seed yield, yield components and morpho-phenological traits using multivariate analyses in safflower (Carthamus tinctorious L.). Annals Biol. Res., 2(3):162-169.

Gopal, G.R., Bagade, A.B., Doijad, S.B. and Jawale, L.N.2014. Path analysis studies in safflower germplasm (Carthamus tinctorius L.). Int. J. Current microbiol. Applied Sci., 3(12): 347-351.

Hoshang, N., Abas, S., Rahim, N. and Samira, N. 2013. Study of correlation between important agronomic traits and path analysis for grain and oil yield in safflower. Int. J. Agron. and Plant Production, 4(4): 670-673.

Hussain, T., Tariq, M.A., Ahmad, I., Muhammad, S., Batool, M., Misbah S., Ahmad S. and Muhammad, T. 2014. Characters association analysis in safflower (Carthamus tinctorius L.). J. Bio., Agril. and Healthcare, 4(6): 63-65.

Jadhav,S.A., Dhuppe, M.V. and Salunke, P.M. 2018. Correlation coefficient and path analysis in safflower (Carthamus tincorius L.).Int. J. Curr. Microbiol. Applied Sci., 6: 1234-1241.

Karimi, M., Golparvar, A. and Shams, M. 2014. Genetic improvement of seed and oil yield in spring Safflower cultivars in stress environments. Applied Sci. Report, 2(2):58-61.

Knowles, P.F. 1976. Centers of plant diversity and conservation of crop germplasm safflower. Econ. Bot., 23: 324-329.

Kumar, R.2010. Variability and character association in safflower (Carthamustinctorius L.).M.Sc.(Ag.) Thesis, Maharana Pratap University of 
Agriculture and Technology, Udaipur, Rajasthan.

Kumar, S. 2016. Genetic divergence studies for yield and its attributes in safflower (Carthamus tinctorius L.) M.Sc.(Ag.) Thesis, Rajmata Vijayaraje Scindia Krishi Vishwavidyalaya, Gwalior (M.P.).

Lenka, D. and Mishra, B. 1973. Path coefficient analysis of yield in rice varieties. Indian J. Agric. Sci., 43: 376-379.

Manjhi, D. 2017. Evaluation for yield and oil content in some exotic lines of safflower (carthamus tinctorius L.). M.Sc. (Ag.) Thesis. Indira Gandhi Krishi Vishwavidyalaya, Raipur, (Chhattisgarh).

Maryam, S.S., Zeinali, H. and Yousefi, E. 2011. Investigation of genetic variation in safflower (Carthamus tinctorius L.) genotypes using agromorphological traits. J. Agric. Sci., 7(2):101- 108

Mohamed, A.K. and Elmogtaba El-Fadl, Y. 2018. Genetic variability and interrelationship for yield and its components in safflower (Carthamus tinctorius L.).Asian Res. J. Agric., 8(4): 1-7.

Nag, P.K. 2015. Heterosis for yield and yield contributing characters in safflower (Carthamus tinctorius L.).M.Sc.(Ag.) Thesis, Indira Gandhi Krishi Vishwavidyalaya, Raipur, Chhattisgarh.

Nezhad, T.H. and Talebi, R. 2015.Interrelationships between agronomic traits with seed yield in safflower (Carthamus tinctorius L.) under different irrigation regimes. Biological Forum- An Int. Journal, 7(2): 430435.

Paikara, S. 2013. Genetic analysis in safflower (Carthamus tinctorius L.). M. Sc. (Ag.) Thesis, Indira Gandhi
Krishi Vishwavidyalaya, Raipur, Chhattisgarh.

Pattar, V.K. 2014. Genetic studies in new safflower (Carthamus tinctorius L.) genotypes. M.Sc. (Ag.) Thesis, College of Agriculture, Dharwad, University of Agricultural Sciences, Dharwad.

Pavithra, K.P., Patil, R.S. and Patil, B.R. 2016a.Estimates of genetic variability parameters of metric traits in safflower (Carthamus tinctorius L.) J. Farm Sci., 29(1): 96-97.

Pavithra, K.P., Patil, R.S., Harijan, Y. and Nishanth, G.K. 2016b.Correlation and path analysis studies in safflower (Carthamus tinctorius L.) germplasm.Res. J. Agri. Sci., 7(2): 428-432.

Pavithra, K.P.2013. Genetic divergence studies in a germplasm collection of safflower (Carthamus tinctorius L.). M.Sc. (Ag.) Thesis, University of Agriculture Sciences, Dharwad.

Perveen, N. 2016. Morphological characterization and identification of plant type of safflower (Carthamus tinctorius $\mathrm{L}$.) for late sown condition. M.Sc.(Ag.) Thesis, Indira Gandhi Krishi Vishwavidyalaya, Raipur, Chhattisgarh.

Pushpavalli, S., Reddy, R.T., Kumar, G. and Sudhakar, C. 2017. Genetic divergence, correlation and path analysis for the yield components of safflower genotypes (Carthamus tinctorius L.). Life Sciences Int. Res. J., 4(1): 2347-8691.

Pushpavalli, S., Sudhakar, C., Jyothi, R. and Raja, R.R. 2015. Correlation and path coefficient analysis for the yield components of safflower germplasm (Carthamus tinctorius L.). El. J. Plant Breeding, 7(2): 420-426.

Salamati, M.S., Zeinali, H. and Yousefi, E. 2011. Investigation of genetic 
variation in (Carthamus tinctorius L.) genotypes using agro-morphological traits.J. Res. Agric. Sci., 7(2): 101108.

Searle, S.R. 1961. Phenotypic, genotypic and environmental correlations. Biometrics, 17: 474-480.

Semahegn, Y. and Tesfaye, M. 2016. Characters associations and path analysis in safflower (Carthamus tinctorious L.) accessions. Molecular Plant Breeding, 7(31): 1-5.

Shivani, D., Sreelakshmi C.H. and Kumar C.V. 2012. Canonical variate analysis in safflower (Carthamus tinctorius L.).El. J. Pl. Breed., 2(4): 563-567.

Shivani, D., Sreelakshmi, C.H. and Kumar, C.V. 2010. Correlation studies in safflower (Carthamus tinctorius L.). El. J. Pl. Breed., 1(5): 1354-1357.

Singh, R.K. and Chaudhary, B.D. 1985. Biometrical methods in quantitative genetic analysis. Kalyani Publishers, New Delhi, Revd. Ed:39-68.
Sirel, Z. and Aytac, Z. 2016. Relationships between the seed yield and some agronomic characteristics of safflower (Carthamus tinctorius L.) under semiarid conditions. Turk. J. Field Crops, 21(1): 29-35.

Snedecor W. and Cochran W.G. (1989). Statistical methods. Oxford and IBM Calcutta. Pp: 593.

Tamoor, H., Ishfaq, A., Saghir, A., Muhammad, M. and Safdar, M., Sher, A. and Tariq, M. 2014.Characters association analysis in safflower (Carthamus tinctorius L.). J. Bio, Agric. and Healthcare, 4(6):63-65.

Valli, P., Sudhakar, C., Rani, J. and Rajeswari, R.R. 2016. Correlation and path coefficient analysis for the yield components of safflower germplasm (Carthamus tinctorius L.). El. J. Pl. Breed., 7(8): 320-324.

Wright, S. 1921. Correlation and causation. $J$. Agric. Res., 20: 257-287.

\section{How to cite this article:}

Monika Paikara and Roshan Parihar. 2019. Character Association and Path Analysis Studies at Genotypic Level on Some Genotypes of Safflower (Carthamus tinctorius L.). Int.J.Curr.Microbiol.App.Sci. 8(03): 2180-2189. doi: https://doi.org/10.20546/ijcmas.2019.803.261 